\title{
Design of creative thinking test in geometry based on information processing taxonomy model
}

\author{
Hevy Risqi Maharani ${ }^{1}$, YL Sukestiyarno, St. Budi Waluya, Mulyono ${ }^{2}$
}

\begin{abstract}
Abstrak: Artikel ini memaparkan tentang bagaimana menghasilkan instrumen yang valid dan reliabel untuk kemampuan berpikir kreatif geometris berdasarkan model taksonomi pemrosesan informasi. Dengan menggunakan model ini, soal geometri dapat diklasifikasikan dalam tingkatan berpikir kreatif siswa berdasarkan proses pengolahan informasi dari pengetahuan matematika yang telah mereka miliki untuk menyelesaikan masalah sesuai batas kriteria pada setiap tingkatannya. Pengembangan instrumen tes mengikuti langkah Beyers (2011). Metode kuantitatif digunakan untuk memvalidasi instrumen soal yang melalui tahap validasi ahli dan validasi instrumen. Hasil penelitian menunjukkan bahwa terdapat lima butir soal geometri yang dapat digunakan untuk mendeskripsikan proses berpikir kreatif siswa pada tingkatan hierarki yang berbeda berdasarkan model taksonomi pemrosesan informasi. Hasil penelitian ini dapat menjadi rujukan untuk guru maupun para peneliti lain untuk menyusun soal matematika dengan memperhatikan tingkatan hierarki kemampuan berpikir siswa agar siswa dengan berbagai kemampuan yang berbeda dapat mengerjakan soal sesuai dengan kemampuan yang mereka miliki.
\end{abstract}

Kata kunci: Berpikir kreatif, Geometri, Taksonomi pemrosesan informasi, Desain tes

\begin{abstract}
This paper describes how to develop a valid and reliable instrument for geometric creative thinking test based on the information processing taxonomy model. Using this model, geometry test can be classified in the level of creative thinking based on the information processing process of the mathematical knowledge they already have to solve problems according to the criteria at each hierarchical level. The development of the test instrument refers to Beyers (2011). A quantitative method was used to validate instruments through experts validation and instrument validation. The results showed that there was five geometry test that can be used to describe the student's creative thinking process at a different hierarchical level based on the information processing taxonomy. The results of this study can be a reference for teachers and other researchers to design mathematical test by paying attention to the hierarchical level of student's thinking abilities so that students with different abilities can solve problems which refer to their abilities.
\end{abstract}

Keywords: Creative thinking, Geometry, Information processing taxonomy, Test design

\section{A. Introduction}

Creative thinking is a life skill that should be developed, especially in the era of information and the competitive atmosphere is getting tighter (Nurmasari, Kusmayadi, \& Riyadi, 2014). Indonesia as a developing country needs creative workers who can contribute to science, technology, and art, as well as the welfare of the nation in general (Wulandari \& Mashuri, 2014). As stated in Curriculum 2013, education aims to prepare Indonesian people to have the ability to live as productive, creative, innovative and effective individuals and citizens. Based on this goal, one of the abilities to be achieved is creative thinking (Sari, Ikhsan, \& Saminan, 2017). This ability can be achieved if mathematics learning in particular focused on the development of creative thinking of students (Alfian, Dwijanto, \& Sunarmi, 2017; Arifah, Rochmad, \& Sugiman, 2016; Hapsari, Supriyono, \& Hendikawati, 2015; Konita, Sugiarto, \& Rochmad, 2017;

\footnotetext{
${ }^{1}$ Sultan Agung Islamic University, Semarang, Indonesia, hevyrisqi@unissula.ac.id

${ }^{2}$ Semarang State University, Semarang, Indonesia
} 
Kwon, Park, \& Park, 2006; Utami, Masrukan, \& Arifudin, 2014; Warda, Mashuri, \& Amidi, 2017; Wijaya, Rochmad, \& Agoestanto, 2016).

Creative thinking in mathematics is more often associated with problem-solving. Pehkonen (1997) stated four reasons why problem-solving is essential to be taught concerning creative thinking. First, problem-solving develops cognitive skills. Second, problem-solving enhances creativity. Third, problem-solving is part of the mathematical application process. Fourth, problem-solving motivates students to learn mathematics.

Geometry is one of the mathematics topics that need attention, especially for secondary school students since they are in a period of transition from the concrete thinking to the abstract thinking process. In general, the student's creative thinking ability in the field of geometry is still relatively low. Maharani and Sukestiyarno (2017) revealed that average test results of student's creative thinking ability in geometry were still in the less creative category. There are no students in the creative or very creative category. It was because students were not familiar with solving problems using various ways. They were accustomed to solving problems with one method following what was taught by the teacher in the classroom. Similarly, Putri, Riyadi, and Subanti (2014) showed that students' creative thinking ability in solving geometry problems both male and female students was in a medium category.

The use of taxonomies can help educators gain perspective on the emphasis given to certain behavior by a set of the specific educational plan. By looking at taxonomic categories, it might provide advice for teachers. For example, the teacher can include several objectives related to the application of knowledge and analyze situations in which knowledge is used (Bloom, Engelhart, Furst, Hill, \& Krathwohl, 1956).

A well-known taxonomy for evaluating students' learning outcomes is Bloom's taxonomy (Munzenmaier \& Rubin, 2013). The main idea of Bloom's taxonomy is that what educators want about what students achieve (stated in the statement of educational goals) can be arranged in a hierarchy from the lowest to a more complex hierarchy. These levels are arranged sequentially so that one level must be mastered before the next level can be achieved (Huitt, 2011). Bloom levels are structured as follows: knowledge, comprehension, application, analysis, synthesis, and evaluation (Bloom et al., 1956; Bonaci, Mustata, \& Ienciu, 2013; Huitt, 2011; IACBE, 2014; Munzenmaier \& Rubin, 2013).

Another technique used to assess students' abilities is the SOLO taxonomy developed by Biggs and Collis in 1982. SOLO taxonomy is used to classify the students' abilities in responding to a problem into five different and hierarchical levels, namely pre-structural, uni-structural, multi-structural, relational, and an extended abstract (O’Neill \& Murphy, 2010; Potter \& Kustra, 2012).

Although both taxonomies (Bloom and SOLO) have proven useful in assessing students' abilities, they have several drawbacks in their implementation. Bloom and SOLO taxonomy is useful for building an item to get student responses at different levels. Both of these taxonomies cannot explain precisely how the cognitive processes in problem-solving to find a solution (Fong, 1994). Therefore, it is necessary to use a taxonomy that is more appropriate to assess mathematical abilities. Thus, we propose the use of information processing taxonomy model.

The information processing taxonomy model according to Fong $(1994,1997)$ contains two essential components, namely: (1) a number of information processing components such as external sources (ES), short-term memory (STM) or working memory (WM) and long-term memory (LTM), and (2) operating systems that include perception through stimulus, retrieving information from ES, and operations based on the primary and secondary production systems. 
The information processing taxonomy helps to build appropriate test items used to assess the ability of mathematics, one of which is the ability of creative thinking in geometry. By using this model, geometry problems can be classified in the level of students' thinking based on the information processing of the mathematical knowledge they already have to solve problems given with specific criteria limits at each level.

The results of Fong's (1994) study showed that the information processing taxonomy model could be used to construct daily problem-solving tests for the topics of the four operations, comparisons, and composite figures. All test items were prepared using information processing taxonomy model based on five different levels. Fong also found that the number of students who achieved the level of decline in line with the increasing levels of difficulty from level 1 to level 5.

Referring to the background of the current research, i.e. the importance of developing creative thinking in mathematics based on Alfian et al. (2017); Arifah et al. (2016); Hapsari et al. (2015); Konita et al. (2017); Kwon et al. (2006); Utami et al. (2014); Warda et al. (2017); Wijaya et al. (2016) and the importance of developing appropriate test items to assess students' mathematical abilities based on (Fong, 1994, 1997), this article aims to describe how to design creative thinking test in geometry based on the information processing taxonomy model.

\section{B. Methods}

The process of developing test instruments in this study was drawn from Beyers (2011). The instrument is a creative thinking test in geometry based on the information processing taxonomy model which follows two development stages: instrument formation and instrument validation (Beyers, 2011). Stage 1 (instrument formation) has four components, namely: 1) reviewing relevant literature, 2) generating items, 3) evaluating items proposed by the expert in mathematics education, and 4) pilot testing draft of instruments. Stage 2 (instrument validation) used statistical methods to obtain the indexes of validity, reliability, level of difficulty, and discrimination of each item. Figure 1 shows the activities that are appropriate for each stage of instrument development.

\section{Stage 1: Instrument Formation}

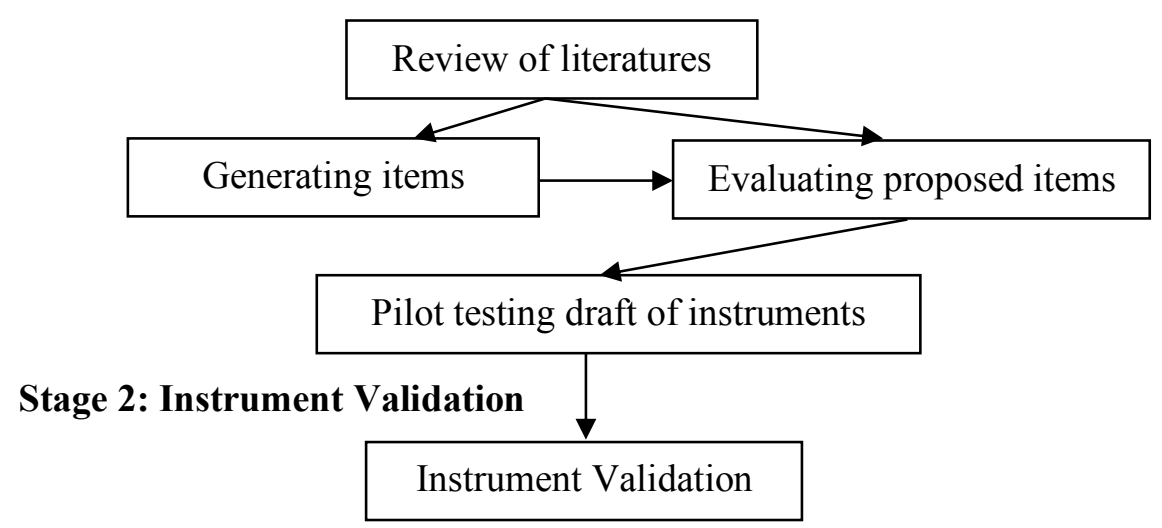

Figure 1. The stages of instrument development

The first stage of the instrument formation was reviewing the relevant literature. In this study, the researchers conducted the pieces of literature review from Fong $(1994,1997)$ to design test items based on the level of information processing taxonomy model as shown in Table 1. The results of the design of the test items were then consulted to experts consisting of 6 experts from Semarang State University, Diponegoro University, and Sebelas Maret University. The 
experts are selected based on their ability in the field of mathematics education so that they can evaluate and provide feedback and on items that have been proposed. Furthermore, the test items were revised according to expert assessment, and the pilot testing draft of the instrument will be conducted.

Table 1. Information processing taxonomy model

\begin{tabular}{cl}
\hline Levels & \multicolumn{1}{c}{ Characteristic Features \& Operating Systems } \\
\hline One & ES, STM/WM; Perception through the stimulus, retrieving information from ES. \\
Two & $\begin{array}{l}\text { ES, STM/WM, LTM (Type A Information); Perception through the stimulus, } \\
\text { retrieving information from ES and primary production system. }\end{array}$ \\
Three & $\begin{array}{l}\text { ES, STM/WM, LTM (Type A \& B Information); Perception through the stimulus, } \\
\text { retrieving information from ES and primary production system. }\end{array}$ \\
Four & $\begin{array}{l}\text { ES, STM/WM, LTM (Type A Information); Perception through the stimulus, } \\
\text { Five }\end{array}$ \\
& $\begin{array}{l}\text { ES, STM/Wing information from ES, primary \& secondary production system. } \\
\text { retrieving information from ES, primary \& secondary production system. }\end{array}$ \\
\hline
\end{tabular}

Source: Fong (1994); Purwoko, Saad, \& Tajudin (2017)

ES is data or information obtained from the problem or question that was asked. All information originating from ES or LTM is processed at STM / WM. This part of the human brain has a limited capacity and can only process several pieces of information at a particular time. There are two types of information that can be stored in LTM. Information related to the recent content area of study and often delivered is classified as type A information, while information on related topics is classified as type B information. Type A information is assumed to be information that is easily remembered or retrieved by students compared to type B information (Fong, 1994).

The research subjects for the instrument testing were the eighth-grade students in Semarang. There were eight classes in which one class was selected by cluster random sampling technique as a pilot testing draft of instrument consisting of 32 students. The results of the pilot testing draft were used to validate the instruments that have been arranged.

\section{Findings and Discussion}

The results of the development of creative thinking test in geometry that has been arranged based on the information processing taxonomy model consist of five items. Five items are arranged about the level ranging from one to five. These levels were arranged sequentially based on specific characteristics and operating systems on the information processing taxonomy model that has been presented by Fong (1994) according to Table 1.

The instrument about the mathematics creative thinking ability on geometry that has been arranged by researchers based on the information processing taxonomy model was first consulted to several experts in the field of mathematics education to evaluate and provide feedback and on items that have been proposed. The evaluation given by the experts refers to the rating scale from 1 to 5. The results of the expert's assessment are analyzed based on the average score given by the expert. The average expert validations score has been converted based on the expert validation criteria which are shown in Table 2.

The results of the evaluation of the experts obtained an average value of 4.38 on a scale of 5 for creative thinking questions based on the information processing taxonomy model. The average value of the validation was included in the very valid criteria. The instrument was then revised according to the suggestion from experts before continuing at the pilot testing draft of the instrument as shown in Table 3. 
Table 2. Expert validation criteria

\begin{tabular}{cc}
\hline $\begin{array}{c}\text { Average } \\
\text { Score }\end{array}$ & Criteria \\
\hline $1,00-1,80$ & Not Valid \\
$1,81-2,60$ & Less Valid \\
$2,61-3,40$ & Quite Valid \\
$3,41-4,20$ & Valid \\
$4,21-5,00$ & Very Valid \\
\hline
\end{tabular}

Table 3. The results of expert evaluations and instrument revisions

\begin{tabular}{|c|c|}
\hline Expert Evaluations & $\begin{array}{c}\text { Instrument Revisions } \\
\end{array}$ \\
\hline $\begin{array}{l}\text { Test instruments need to be made more } \\
\text { varied, and some questions need to be } \\
\text { corrected so that the questions } \\
\text { encourage students to think creatively }\end{array}$ & $\begin{array}{l}\text { Test instruments have been made more varied } \\
\text { according to indicators of creative thinking ability }\end{array}$ \\
\hline $\begin{array}{l}\text { Scoring guidelines need to pay attention } \\
\text { to the criteria for each indicator of } \\
\text { creative thinking }\end{array}$ & $\begin{array}{l}\text { Scoring guidelines have been improved so that they } \\
\text { can measure each criterion of creative thinking } \\
\text { indicators }\end{array}$ \\
\hline $\begin{array}{l}\text { A question at level } 4 \text { needs to be revised } \\
\text { so that the learning indicator in solids } \\
\text { will be achieved }\end{array}$ & $\begin{array}{l}\text { A question at level } 4 \text { has been revised so that the } \\
\text { learning indicator in solids will be achieved }\end{array}$ \\
\hline $\begin{array}{l}\text { Some writing formats for mathematical } \\
\text { formulas need to be corrected }\end{array}$ & $\begin{array}{l}\text { The format of writing mathematical formulas have } \\
\text { been corrected }\end{array}$ \\
\hline
\end{tabular}

The draft instrument of questions that have been through the revision and the expert validation consisting of 5 items are as follows.

\section{1) Level 1 question}

Draw a wide variety of nets cube with a length of 3 units in the terraced paper that has been provided!

The question at level 1 has a clear output source (ES) and no hidden information and can be solved with working memory (STM / WM) only. Therefore, this question is in accordance with level 1, namely working memory or short-term memory stages. Representation of the creative thinking in solving question level 1 can be seen in Figure 2.

Figure 2 shows that an information source is operated on the STM. (1'), the terraced paper and a length of the net are three units, and (2'), draw a wide variety of nets cube, a set of information obtained from ES. The information is then processed in STM to produce several cube nets according to the paper provided.

The question at level 1 allows students to recall knowledge of the procedure for drawing nets so that a cube can be formed by displaying various examples of cube nets on the provided paper. Judging from the cognitive dimension, the level 1 involves the process of remembering and understanding, so that this problem belongs to the level 2 in Bloom's taxonomy (Bloom et al., 1956; Bonaci et al., 2013; Huitt, 2011; IACBE, 2014; Munzenmaier \& Rubin, 2013).

\section{2) Level 2 question}

The roof of a pyramidal building with a base in the form of a square measuring $18 \mathrm{~m} \times 18 \mathrm{~m}$. The roof height (pyramid height) is $9 \mathrm{~m}$. Determine the volume of air contained in the building! 


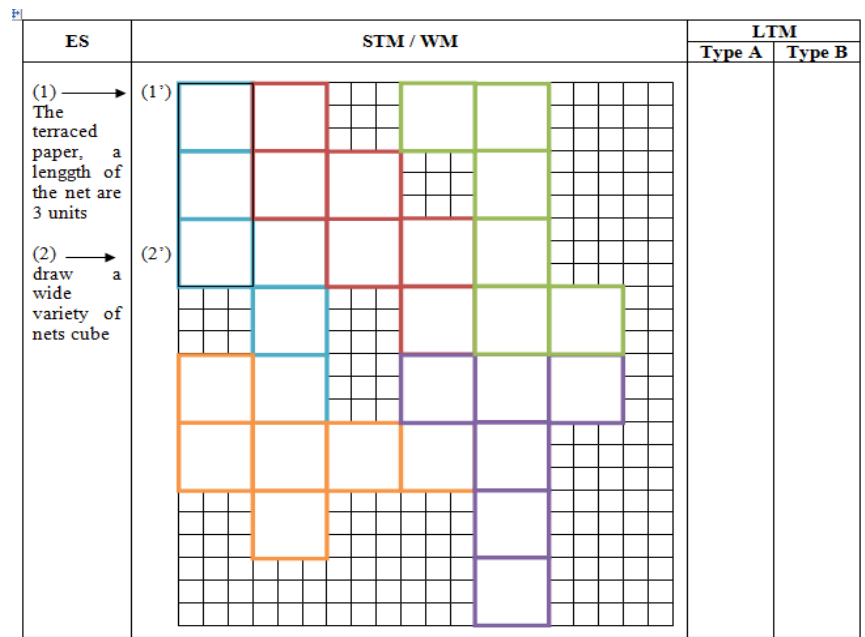

Figure 2. Representation of creative thinking in solving the question at level 1

The question at level 2 can be solved using the volume of pyramid formula. Therefore, this problem has involved retrieving information from long-term memory (LTM) type A. Information that has been obtained from long-term memory is then received and operated on the STM to obtain a solution to the question. Representation of the creative thinking process at level 2 can be seen in Figure 3.

Figure 3 shows that two sources of information are operated on the STM. (1'), the roof of a pyramidshaped building, $\mathrm{s}=18 \mathrm{~m}, \mathrm{t}=9 \mathrm{~m}$, and ( $\left(2^{\prime}\right)$, determine the volume of air contained in the building, is a set of information obtained from ES. Information ( $3^{\prime}$ ), the volume of a pyramid, is obtained from LTM. Both information obtained from the ES and LTM is operated on the STM to produce (4), 972.

The question at level 2 allows students to remember and relate the information contained in the problem which in turn requires students to retrieve information from type A LTM, which is the volume of pyramid formula and apply the formula to solve the problem. Judging from the cognitive dimension, the question at level 2 involves the process of applying, remembering and understanding, so that this problem belongs to the level 3 in Bloom's taxonomy (Bloom et al., 1956; Bonaci et al., 2013; Huitt, 2011; IACBE, 2014; Munzenmaier \& Rubin, 2013).

\begin{tabular}{|c|c|c|c|}
\hline \multirow{2}{*}{ ES } & \multirow{2}{*}{ STM / WM } & \multicolumn{2}{|c|}{ LTM } \\
\hline & & Type A & Type B \\
\hline$(1)$ & $\left(1^{\prime}\right)-$ & (3) & \\
\hline $\begin{array}{l}\text { The roof of a } \\
\text { pyramid- } \\
\text { shaped } \\
\text { building, } s=18 \\
\mathrm{~m}, t=9 \mathrm{~m}\end{array}$ & $\begin{array}{l}V_{\text {limas }}=\frac{1}{3} \times \text { base area } \times t \\
\text { or } V_{\text {limas }}=\frac{1}{6} \times V_{\text {cubs }}\end{array}$ & $\begin{array}{l}\text { The } \\
\text { volume } \\
\text { of } \\
\text { pyramid }\end{array}$ & \\
\hline (2) $\longrightarrow$ & $\left(2^{\prime}\right)-$ & & \\
\hline $\begin{array}{l}\text { Determine the } \\
\text { volume of air } \\
\text { contained in the } \\
\text { building }\end{array}$ & $\begin{array}{l}V=\frac{1}{3} \times 18 \times 18 \times 9 \text { or } \\
V=\frac{1}{6} \times 18 \times 18 \times 18\end{array}$ & & \\
\hline $\begin{array}{l}\text { Answer: } \\
\text { The volume of } \\
\text { air contained in } \\
\text { the building is } \\
972 \mathrm{~m}^{3} \text {. }\end{array}$ & (4) $V=972$ & & \\
\hline
\end{tabular}

Figure 3. Representation of the creative thinking process in solving the question at level 2 


\section{3) Level 3 question}

Some unit cubes are arranged into blocks measuring $5 \times 3 \times 4$ units of volume. Then the cubes without adding and subtracting the number will be formed into another block. Determine all possible new block sizes that can be made!

The question at level 3 can be solved by using the volume of cuboid formula and the factorization concept. Therefore, this question has involved retrieving information from type A long-term memory (LTM) by remembering the cuboid volume followed by retrieval of information from type B long-term memory (LTM) which is considering the factorization concept. Information from the LTM is then received and interpreted on the STM to solve the problem. Representation of the creative thinking process at level 3 can be seen in Figure 4.

The topic to be assessed on the question at level 3 is the solids. As a result, all skills related to the solid theme can be classified as type A information. As explained in Figure 4, "the volume of a cuboid" is classified as type A information. The statement "the factors of cuboid volume" is not a direct skill related to the topic of the solids in geometry so that it can be classified as type B information. A set of information either in the form of type A information or type B information is obtained from LTM.

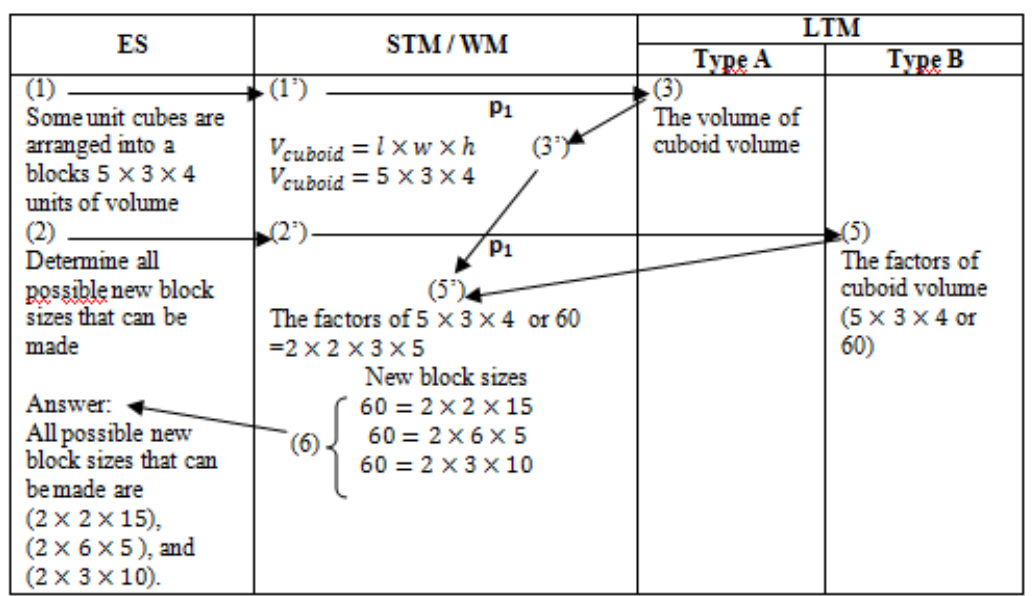

Figure 4. Representation of the creative thinking process in solving the question at level 3

The question at level 3 allows students to remember and relate the information contained in the question which then requires students to retrieve information from LTM type A, namely the volume of the cuboid used to determine the volume of the initial block. Students can determine the size of the new block by selecting three numbers which, if multiplied, will have the same volume as the size of the initial block. It can be done by looking for a number factor from the initial block volume. Judging from the cognitive dimension of question at level 3 involves the process of evaluating, analyzing, applying, remembering and understanding, so that this problem belongs to the level 5 in Bloom's taxonomy (Bloom et al., 1956; Bonaci et al., 2013; Huitt, 2011; IACBE, 2014; Munzenmaier \& Rubin, 2013).

\section{4) Level 4 question}

A stacking rack consisting of 3 congruent rectangular prisms with a size of $70 \mathrm{~cm} \times 20 \mathrm{~cm}$ $x 10 \mathrm{~cm}$. Determine the area of fiber needed to make the stacking rack! 
The question at level 4 can be solved using the formula of the surface area of the quadrilateral prism, or it can also be solved using the surface area of the cuboid. Figure 5 shows that the first production of the information obtained is the surface area of the quadrilateral prism or cuboid surface area which involves taking from type A LTM. After obtaining the results from the calculation of surface area processed in the STM, a second production will be carried out from the information obtained by doing the technique or procedure to get the overall surface area. Furthermore, the technique or procedure will be processed in the STM to obtain a solution to the question. Representation of the creative thinking process in solving the question at level 4 can be seen in Figure 5.

As a question at level 3, the matter to be assessed at hierarchical levels 4 is the solid theme. As a result, all skills related to the solid theme can be classified as type A information. As explained in Figure 5, "surface area of quadrilateral prism" can be classified as type A information. Information obtained from the LTM will be processed in STM to search one-piece rack surface area. Furthermore, a second production process is needed, namely by applying the "technique to get the overall surface area" so that the overall surface area is 13,800 .

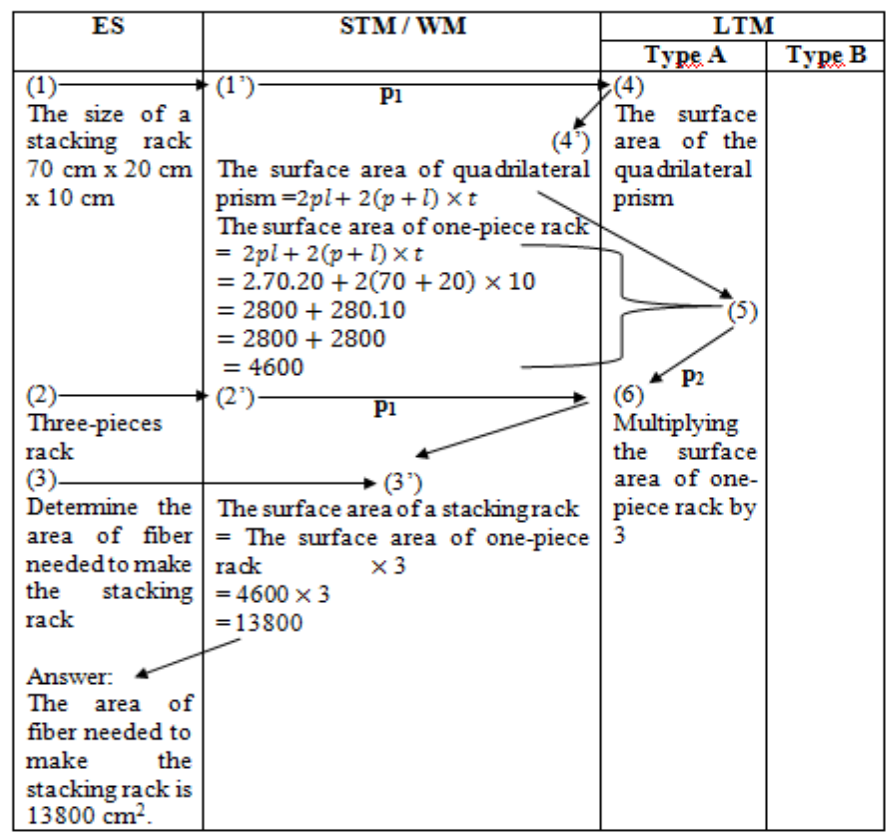

Figure 5. Representation of the creative thinking process in solving the question at level 4

The question at level 4 when viewed from the dimension of knowledge, this problem has reached the stage of metacognitive knowledge where the cognitive processes experienced by students include evaluating, analyzing, applying, remembering and understanding. Students remember and relate the information contained in the problem which then requires students to retrieve information from LTM type A, namely the surface area of quadrilateral prisms. After that students must determine the overall surface area of the three stacking rack. Judging from the cognitive dimension, the question at level 4 involves the process of evaluating, analyzing, implementing, remembering and understanding, so that this problem belongs to the level 5 domain in Bloom's taxonomy (Bloom et al., 1956; Bonaci et al., 2013; Huitt, 2011; IACBE, 2014; Munzenmaier \& Rubin, 2013). 


\section{5) Level 5 question}

The volume of a cuboid-shaped swimming pool is $64 \mathrm{~m}^{3}$. If the ratio of the length, width, and height of the cuboid is 4: 2: 1, determine the size of the swimming pool!

The question at level 5 can be solved by involving the retrieval of information from LTM type A, namely the volume of cuboid formula and retrieval of information from the LTM type $\mathrm{B}$, namely the concept of comparison. Both of information are then processed at STM so that the first production results are obtained where " $x=2 "$. Next, it is necessary to do a second production process to determine each size in the swimming pool by submitting the value obtained in the first production result. This process requires type B information retrieval, namely the concept of substitution. The representation of the process of solving the problem of hierarchical level questions 5 can be seen in Figure 6.

Figure 6 shows that the primary and secondary production of information is processed to produce information from the secondary source. The primary production is a method of determining the size of the length, width, and height of a swimming pool by using the concept of "the volume of swimming pool = the volume of cuboid", while the secondary production is a technique for substituting the value of $x$ to the ratio of length, width, and height.

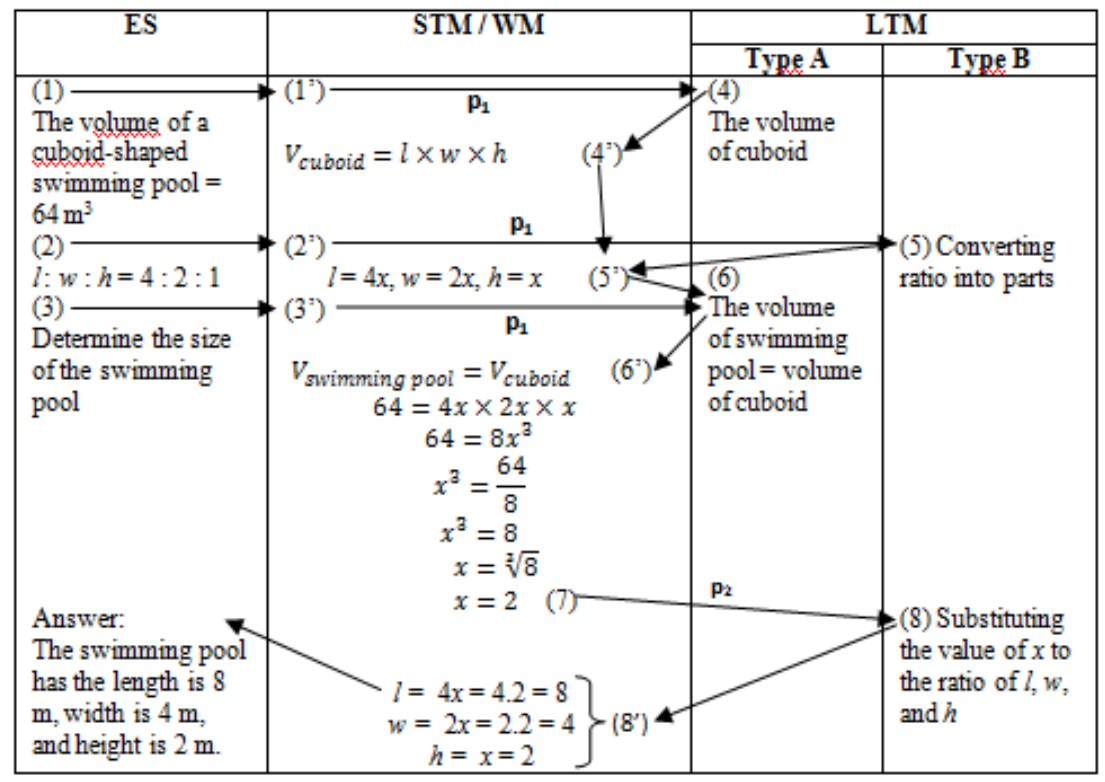

Figure 6. Representation of the creative thinking process in solving the question at level 5

The question at level 5 allows students to remember and relate the information contained in the question which then requires students to retrieve information from LTM type A, namely the volume of the cuboid and information from LTM type B, namely the concept of comparison. The comparison concept will be used by students to make mathematical models of the comparison of swimming pool sizes. After the mathematical model is created, students can make mathematical operations until a solution is obtained. The results of the mathematical operations are then changed back to answer the problem given. Judging from the cognitive dimension, the level 5 involve the process of evaluating, analyzing, applying, remembering and understanding, so that this problem belongs to the level 5 in Bloom's taxonomy (Bloom et al., 1956; Bonaci et al., 2013; Huitt, 2011; IACBE, 2014; Munzenmaier \& Rubin, 2013). 
The draft instrument on creative thinking ability based on the information processing taxonomy model that has passed the expert validation was then through the pilot testing draft. There were four steps of instrument validation to obtain the indexes of validity, reliability, level of difficulty, and discrimination of each item. The results of instrument validation are presented in Table 4.

Table 4. The results of instrument validation

\begin{tabular}{ccccc}
\hline No & Validity & Reliability & Difficulty & Discrimination \\
\hline 1 & 0,763 & & 0,82 & 0,50 \\
& (Valid) & & $($ Easy) & $(\mathrm{Good})$ \\
2 & 0,804 & & 0,65 & 0,44 \\
& $($ Valid) & & (Medium) & $(\mathrm{Good})$ \\
3 & 0,772 & 0,793 & 0,64 & 0,44 \\
& $($ Valid) & (Reliable) & (Medium) & $(\mathrm{Good})$ \\
4 & 0,633 & & 0,62 & 0,50 \\
& $($ Valid) & & (Medium) & $(\mathrm{Good})$ \\
5 & 0,734 & & 0,52 & 0,58 \\
& (Valid) & & (Medium) & $(\mathrm{Good})$ \\
\hline
\end{tabular}

Table 4 shows that the test items that have been proposed have met the criteria of validity and reliability. It means that the test items can be used as research instruments to assess and describe students' creative mathematical thinking processes at different hierarchical levels based on the information processing taxonomy model. The level of difficulty of the items shows that the level of difficulty increases from item number 1 to item number 5. This hierarchy pattern is following the hypothesis of the information processing taxonomy model. It is accordance with the results of study conducted by Fong (1994) which states that the test instrument is based on a model taxonomic information processing can determine the level of thinking of the cognitive process using mathematical knowledge based on specific characteristics, such as the primary and secondary production as well as information types A and B obtained from the LTM.

\section{Conclusion}

The information processing taxonomy models can be used to construct tests of creative thinking ability on geometry at each different level based on current characteristics. Using this model, the test of creative thinking ability can be classified into five levels of thinking based on the specific characteristics of information processing in solving problems. The results of this study can be used as guidelines for teachers in designing and analyzing questions based on the information processing taxonomy model. Teachers in constructing questions need to pay attention to the level of student's thinking abilities so that students with different abilities can solve the problems according to their abilities. The further research can also utilize this information processing taxonomy model to build a test that aims to analyze student's thinking processes in solving problems.

\section{References}

Alfian, M. H., Dwijanto, \& Sunarmi. (2017). Effectiveness of probing-prompting learning models with scaffolding strategy to mathematics creative thinking ability and enthusiasm. Unnes Journal of Mathematics Education, 6(2), 249-257. Doi: 10.15294/ujme.v6i2.17172

Arifah, Y. N., Rochmad, \& Sugiman. (2016). Keefektifan model pembelajaran CORE berbantuan strategi 
studi kasus terhadap kemampuan berpikir kreatif siswa SMP. Unnes Journal of Mathematics Education, 5(2), 124-130.

Beyers, J. (2011). Development and evaluation of an instrument to assess prospective teachers ' dispositions with respect to mathematics. International Journal of Business and Social Science, 2(16), $20-32$.

Bloom, B. S., Engelhart, M. D., Furst, E. J., Hill, W. H., \& Krathwohl, D. R. (1956). The classification of educational goal. In Taxonomy of Educational Objective (pp. 1-201). New York: David McKay Company Inc.

Bonaci, C. G., Mustata, R. V, \& Ienciu, A. (2013). Revisiting Bloom's taxonomy of educational objectives. The Macrotheme Review A Multidisciplinary Journal of Global Macro Trends, 2(2), 1-9.

Fong, H. K. (1994). Information processing taxonomy (IPT): An alternative technique for assessing mathematical problem-solving. Singapore Journal of Education, 14(1), 31-45.

Fong, H. K. (1997). Children's productive thinking in solving a ratio and proportion problem. The Mathematics Educator, 2(2), 128-137.

Hapsari, D. T., Supriyono, \& Hendikawati, P. (2015). Keefektifan model pembelajaran missouri mathematics project berbantuan media POMAT terhadap kemampuan berpikir kreatif matematis siswa kelas VII materi Segitiga. Unnes Journal of Mathematics Education, 4(3), 251-256.

Huitt, W. (2011). Bloom et al.'s taxonomy of the cognitive domain. In Educational Psychology Interactive (pp. 1-4). Valdosta, GA. Retrieved from http://www.edpsycinteractive.org/topics/cognition/bloom.html

IACBE. (2014). Bloom's taxonomy of educational objectives and writing intended learning outcomes statements. Lenexa: IACBE. Retrieved from http://iacbe.org/wp-content/uploads/2017/09/BloomsTaxonomy-of-Educational-Objectives-partial.pdf

Konita, M., Sugiarto, \& Rochmad. (2017). Analysis of students ability on creative thinking aspects in terms of cognitive style in mathematics learning with CORE Model using constructivism approach. Unnes Journal of Mathematics Education, 6(1), 63-70. Doi: 10.15294/ujme.v6i1.12496

Kwon, O. N., Park, J. S., \& Park, J. H. (2006). Cultivating divergent thinking in mathematics through an open-ended approach. Asia Pacific Education Review, 7(1), 51-61. Doi: 10.1007/BF03036784

Maharani, H. R., \& Sukestiyarno, Y. (2017). Learning analysis based on humanism theory and mathematics creative thinking ability of students. Proceedings of International Conference on Mathematics: Education, Theory, and Application (ICMETA) (Vol. 1, pp. 218-225).

Munzenmaier, C., \& Rubin, N. (2013). Bloom's taxonomy: What's old is new again. Retrieved from http://onlineteachered.mit.edu/edc-pakistan/files/best-practices/session-2/Pre-Session-MunzenmaierRubin-2013.pdf

Nurmasari, N., Kusmayadi, T. A., \& Riyadi. (2014). Analisis berpikir kreatif siswa dalam menyelesaikan masalah matematika pada materi peluang ditinjau dari gender siswa kelas XI IPA SMA Negeri 1 Kota Banjarbaru Kalimantan Selatan. Jurnal Elektronik Pembelajaran Matematika, 2(4), 351-358.

O’Neill, G., \& Murphy, F. (2010). Guide to taxonomies of learning. Dublin: UCD. Retrieved from http://www.ucd.ie/t4cms/ucdtla0034.pdf

Pehkonen, E. (1997). Fostering of mathematical creativity: The state of art in mathematical creativity. ZDM, 29(3), 63-67.

Potter, M. K., \& Kustra, E. (2012). A Primer on learning outcomes and the SOLO taxonomy. Center for Teaching and Learning, University of Windsor. Retrieved from http://www.uwindsor.ca/ctl/sites/uwindsor.ca.ctl/files/primer-on-learning-outcomes.pdf

Purwoko, Saad, N. S., \& Tajudin, N. M. (2017). Junior high school students' cognitive process in solving the developed algebraic problems based on information processing taxonomy model. In AIP Conference Proceedings (pp. 0300061-0300066). American Institute of Physics. Doi: $10.1063 / 1.4983883$

Putri, A. Y., Riyadi, \& Subanti, S. (2014). Kreativitas dalam memecahkan masalah geometri bangun ruang sisi datar siswa kelas VIII SMPN 1 Arjosari Kabupaten Pacitan Tahun Pelajaran 2013 / 2014 ditinjau dari gaya kognitif dan gender. Jurnal Elektronik Pembelajaran Matematika, 2(10), 1119 1130.

Sari, A. P., Ikhsan, M., \& Saminan. (2017). Proses berpikir kreatif siswa dalam memecahkan masalah matematika berdasarkan model Wallas. Beta: Jurnal Tadris Matematia, 10(1), 18-32. Doi: 10.20414/betajtm.v10i1.102.

Utami, A. F., Masrukan, \& Arifudin, R. (2014). Meningkatkan kemampuan berpikir kreatif siswa melalui pembelajaran model taba berbantuan Geometer's Sketchpad. Jurnal Kreano, 5(1), 63-72. 
Warda, A. K., Mashuri, \& Amidi. (2017). The effectiveness of SSCS learning model with KNWS strategy towards mathematical creative thinking ability and self confidence of students. Unnes Journal of Mathematics Education, 6(3), 308-317.

Wijaya, L., Rochmad, \& Agoestanto, A. (2016). Analisis kemampuan berpikir kreatif matematis siswa SMP Kelas VII ditinjau dari tipe kepribadian. Unnes Journal of Mathematics Education, 5(2), 84-91.

Wulandari, N., \& Mashuri. (2014). Keefektifan pembelajaran CIRC dengan pendekatan open-ended terhadap kemampuan berpikir kreatif siswa kelas VIII materi kubus-balok. Unnes Journal of Mathematics Education, 3(3), 231-240. Doi: 10.15294/ujme.v3i3.4489 